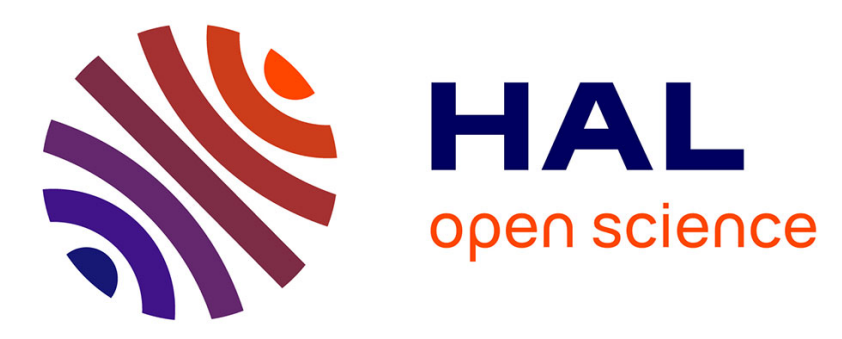

\title{
Numerical Modelling of Combined Heat Transfers in a Double Skin Façade - Full Scale Laboratory Experiment Validation
}

\author{
Frédéric Kuznik, Tiberiu Catalina, Lucie Gauzere, Monika Woloszyn, \\ Jean-Jacques Roux
}

\section{To cite this version:}

Frédéric Kuznik, Tiberiu Catalina, Lucie Gauzere, Monika Woloszyn, Jean-Jacques Roux. Numerical Modelling of Combined Heat Transfers in a Double Skin Façade - Full Scale Laboratory Experiment Validation. Applied Thermal Engineering, 2011, 31 (14-15), pp.3043. 10.1016/j.applthermaleng.2011.05.038 . hal-00781339

\author{
HAL Id: hal-00781339 \\ https://hal.science/hal-00781339
}

Submitted on 26 Jan 2013

HAL is a multi-disciplinary open access archive for the deposit and dissemination of scientific research documents, whether they are published or not. The documents may come from teaching and research institutions in France or abroad, or from public or private research centers.
L'archive ouverte pluridisciplinaire HAL, est destinée au dépôt et à la diffusion de documents scientifiques de niveau recherche, publiés ou non, émanant des établissements d'enseignement et de recherche français ou étrangers, des laboratoires publics ou privés. 


\section{Accepted Manuscript}

Title: Numerical Modelling of Combined Heat Transfers in a Double Skin Façade - Ful Scale Laboratory Experiment Validation

Authors: Frédéric Kuznik, Ph.D Tiberiu Catalina, Lucie Gauzere, Monika Woloszyn, Jean-Jacques Roux

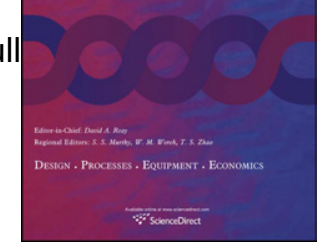

PII:

S1359-4311(11)00298-5

DOI:

10.1016/j.applthermaleng.2011.05.038

Reference: $\quad$ ATE 3585

To appear in: Applied Thermal Engineering

Received Date: 20 October 2010

Revised Date: 6 May 2011

Accepted Date: 28 May 2011

Please cite this article as: F. Kuznik, T. Catalina, L. Gauzere, M. Woloszyn, J.-J. Roux. Numerical Modelling of Combined Heat Transfers in a Double Skin Façade - Full Scale Laboratory Experiment Validation, Applied Thermal Engineering (2011), doi: 10.1016/j.applthermaleng.2011.05.038

This is a PDF file of an unedited manuscript that has been accepted for publication. As a service to our customers we are providing this early version of the manuscript. The manuscript will undergo copyediting, typesetting, and review of the resulting proof before it is published in its final form. Please note that during the production process errors may be discovered which could affect the content, and all legal disclaimers that apply to the journal pertain. 


\title{
Numerical Modelling of Combined Heat Transfers in a Double Skin Façade - Full Scale Laboratory Experiment Validation
}

\author{
Frédéric Kuznik ${ }^{\mathrm{a}, *}$, Tiberiu Catalina ${ }^{\mathrm{b}}$, Lucie Gauzere ${ }^{\mathrm{c}}$, Monika Woloszyn ${ }^{\mathrm{a}}$, \\ Jean-Jacques Roux ${ }^{a}$ \\ ${ }^{a}$ Université de Lyon, CNRS \\ INSA-Lyon, CETHIL, UMR5008, F-69621, Villeurbanne, France \\ Université Lyon 1, F-69622, France \\ ${ }^{b}$ Technical University of Civil Engineering, Bucharest, Romania \\ ${ }^{c} E D F$ RED , département EnerBAT \\ Avenue des Renardières - Ecuelles - r7818 MORET SUR LOING
}

\begin{abstract}
The present paper presents a numerical modelling of a double skin façade (DSF). The model developed includes a zonal model approach for the mass transfer based on the pressure difference in the DSF. The radiative and convective heat transfers are also taken into account to obtain a global coupling between the different phenomena. A full-scale DSF has been experimentally studied in summer configuration with different airflow rates through the air channels of the façade and for different angles of the solar shading devices. First the numerical modelling has been validated using the experimental data. Then, The model has been used to study the influence of airflow rates and blades angles (Venetian blind) on heat transfer in DSF.
\end{abstract}

Keywords: Double Skin Façade, Numerical Modelling, Full-scale

\footnotetext{
*Corresponding author. Tel.: +33-472-438-461; Fax: +33-472-438-522

Email address: frederic.kuznik@insa-lyon.fr (Frédéric Kuznik)
} 
experiment, Venetian Blinds.

\section{Introduction}

Double skin façades (DSF) are architectural elements that have increased in popularity in modern buildings and renovations. They can be found in many projects, especially in office buildings. A fully glazed façade brings the transparency that is often desired by architects when designing an office building. The DSF seams are also interesting features, notably in terms of sound insulation, thermal comfort, visual comfort or energy gain [1].

In the current context of global warming, depletion of fossil fuels and increasing costs of energy consumption, the target is to obtain energy reduction while maintaining correct indoor comfort. To achieve these objectives, it is essential to optimize different parts of active façades and, in particular, for double skin façades. The advantages of using a DSF are located on two levels: during the winter period, the solar energy is used to heat the air in the façade [2], and, in summer, it reduces the overheating periods [3].

A double skin façade consists of a double glazing separated by a ventilated air space with two openings at the top and bottom of the façade. Generally, it can also be equipped with internal or external shading devices. In this article, Venetian blinds are assumed to be located in the air channel between the two glazed panes. Following this definition, a double skin façade can have different configurations, and an example of the geometry can be found in Figure 1.

The first two groups of DSFs are the double skin façades with a large cavity width $(0.5 m-1 m)$, such as the one studied in the research work of 
$\mathrm{Xu}$ et al. [4], and those with a small air channel $(0.10 m-0.3 m)$, like the one studied in this article. Some other DSFs that can also be considered are those with high rise, with a single channel, as in the case of the Occidental Chemical Center in New York City cited in the research study of Poirazis [5], or DSFs of smaller dimensions. These DSFs are less practical from a cleaning and energy efficiency point of view.

DSFs can also be mechanically or naturally ventilated. Four configurations are possible by varying the inlet and outlet air (indoor air-indoor air, outdoor air-outdoor air, indoor air-outdoor air, outdoor air-indoor air), depending on the desired indoor climate conditions.

A key issue of double skin façades is to avoid overheating, especially in summer. Thus, DSFs are equipped with different types of solar protection blinds. Then the research can focus on the influence of the cavity and the air temperature on the air velocity field based on the position (inside, outside or between the cavities), color and angle of the blinds. Few studies have considered this problem because of the lack of multi-parameter studies. The glass properties are also very important concerning the summer thermal comfort [6].

Finally the behaviour of double skin façades depends greatly on the external conditions, and thus different orientations [7] or different season configurations [8] may be analyzed. One possible research objective on double skin façades is to use a control system for the various parameters mentioned above that will reduce the energy consumption while attempting to maintain acceptable thermal comfort for the occupants. Park et al. [9] proposed strategies for controlling the tilt angle of the blinds and the ventilation of 
the double skin.

Concerning the DSF models, Poirazis [5] described two types of numerical models, the CFD numerical modelling (Computational Fluid Dynamics) approach and the "network" numerical modelling. Generally, the numerical models combine CFD modelling of airflow and nodal modelling of other phenomena. In the case of nodal models, two-dimensional studies are generally performed.

For the nodal models, the channel inside the façade is cut into strips and describes the radiation exchange, convection and mass transfer, including identifying coefficients for each transfer. Safer et al. [10] determined the convective heat transfer coefficients of convective and radiative transfer from the velocity and air temperature in the cavity through a CFD model including a turbulence model.

The results of the $2 D$ double skin façade turbulent regime were analysed by Safer et al. [11] and showed the influence of the tilt angle of the shading devices, the position of the blinds in the cavity and the position of the inlet/outlet.

Other approaches such as the dimensionless model [12], a "common" model suitable for testing specific DSF [13], an optical model, CFD [14] and global [15] have also been developed.

The objective of this study is to describe a new approach for the simulation of DSFs in terms of combined heat transfers. The main objective of this model is to develop a model that can be used for the evaluation of DSFs integrated in a building for at least one year. Thus, the model must be physical (all of the heat transfer processes must be taken into account), accurate 
(nodal modelling) and computationally fast (numerical solving process and hypothesis).

The first part of the paper (part 2) describes the numerical modelling of a DSF, the assumptions and particularly the zonal model used to predict the mass transfer in the cavity. The numerical modelling can only be validated through accurate experimental data. Then part 3 of the paper is dedicated to the description of the full-scale laboratory experiment used in this study. The numerical modelling and experimental data are compared in part 4 of this paper. Useful conclusions concerning the use of DSFs are developed in part 5.

\section{DSF numerical modelling}

To model the double skin façade, the combined heat and mass transfer are modelled:

- mass transfer - section 2.1

- radiative heat transfer - section 2.2

- convective heat transfer - section 2.3

Once the combined heat and mass transfers are modelled, the thermal energy balance (part 2.4) is developed to solve the coupled problem.

\subsection{Mass transfer modelling}

A zonal model is an intermediate approach between CFD and multizone models. This approach has the convenience of simplicity in terms of problem definition and calculation procedure, and there is a considerable 
computational time reduction. Several authors, like Saelens [16], Jiru et al. [17] or Stec et al. [18], have used the zonal models to understand the airflow inside the DSF. In our study, a similar approach is used with the difference that a detailed look at the influence of the Venetian blinds and ventilation rate is studied, and it is compared to the experimental data.

For the modelling process, the space in the DSF is discretized in $n$ horizontal bands (see Figure 3). For each of the cells $i$, the variables are the exterior glazing temperature $T_{1}(i)$, the left channel temperature $T_{\text {air }}(i, 1)$, the shading blinds temperature $T_{b}(i)$, the right channel temperature $T_{a i r}(i, 2)$ and the interior glazing temperature $T_{2}(i)$. The assumptions of two channels coupled via the Venetian blinds are justified by previous CFD studies (see Figure 2).

The zonal model is developed by assuming that the cavity internal airflows are functions of the internal pressure difference as proposed by Saelens [16]:

$$
Q_{\text {mass }}=\rho_{\text {in }} K A|\Delta p|^{n}
$$

Based on the Safer research work, the airflow inside the façade is turbulent and thus $n=0.5$. The cavity is divided into horizontal stripes with a height equal to the shading blind length. For each of the cells, the air mass balance can be written, so $2 n$ equations are obtained with the pressures as unknowns. The advantage of using this discretization is that the airflow $Q_{a}$ between the cells of the same stripe can be considered as a Poiseuille plane flow, and the $K$ coefficients can be calculated based on the geometrical characteristics of the DSF. However, knowing that there is a large amount of shading blinds, the large number of equations to be solved and the processing time could slow this process, and, thus, it cannot be considered as a simple and faster model. An arbitrary discretization is preferred, which can reduce the number 
of equations but at the same time increase the difficulty in determining the $K$ coefficients for different flows. Each cell is defined by the couple $i, j$, where $i$ indicates the line location and $j$ takes the value 1 or 2 , depending on the cavity side, the left or the right part. The cells are assumed to have an uniform pressure $p(i, j)$. For each case (see Figure 3), three mass flows are calculated:

$$
\begin{aligned}
& Q_{a}=\rho_{\text {in }} K_{a} A\left|\Delta p_{a}\right|^{n} \\
& Q_{b}=\rho_{i n} K_{b} A\left|\Delta p_{b}\right|^{n} \\
& Q_{c}=\rho_{\text {in }} K_{c} A\left|\Delta p_{c}\right|^{n}
\end{aligned}
$$

with

$$
\begin{gathered}
\Delta p_{a}(i, j)=p(i, 1)-p(i, 2) \\
\Delta p_{b}(i, j)=p(i, 1)-p(i-1,1) \\
\Delta p_{c}(i, j)=p(i, 1)-p(i+1,1)
\end{gathered}
$$

The mass balance for the cell can be written as

$$
\sum_{v} Q_{m a s s-v}=Q_{a}(i, j)+Q_{b}(i, j)+Q_{a}(i, j)=0
$$

where $v$ is the interface with an adjacent cell. The mass balance can be further presented as follows:

$f(i, j)=\operatorname{sign}\left(\Delta p_{a}(i, j)\right) Q_{a}(i, j)+\operatorname{sign}\left(\Delta p_{b}(i, j)\right) Q_{b}(i, j)+\operatorname{sign}\left(\Delta p_{c}(i, j)\right) Q_{c}(i, j)=0$

Proceeding with the mass balance for all the cases, a $2 n$-dimensional vector of equations is

$$
\mathbf{f}=\left\{f_{k}\right\}_{k=1 \ldots 2 n}=\{f(i, 1)\}_{k=1 \ldots n} \cup\{f(i, 2)\}_{k=1 \ldots n}
$$

The unknown vector is

$$
\mathbf{p}=\left\{p_{k}\right\}_{k=1 \ldots 2 n}=\{p(i, 1)\}_{k=1 \ldots n} \cup\{p(i, 2)\}_{k=1 \ldots n}
$$


The first boundary condition is the inlet outdoor air flow $Q_{e x t}$, and, based on Figure 3, it is clear that

$$
Q_{b}(1,1)=-Q_{e x t}
$$

Moreover, the reference pressure is imposed to be the external pressure $P_{e x t}$ in the upper part of the DSF, so the final flow is written as

$$
Q_{c}=\rho_{i n} K_{c} A\left|p(n, 1)-p_{\text {ext }}\right|^{n}
$$

To calculate the mass flows for each cell, the air density is calculated based on the outdoor temperature in the upper/lower part of the DSF and a temperature vector written as

$$
\begin{gathered}
T_{a i r}=\left\{T_{a i r, k}\right\}_{k=1 . .2 n}=\left\{T_{a i r, k}(i, 1)\right\}_{k=1 . . n} \cup\left\{T_{a i r, k}(i, 2)\right\}_{k=1 . . n} \\
\rho=\left\{\rho_{k}\right\}_{k=1.2 n}=\left\{\rho_{k}(i, 1)\right\}_{k=1 . .2} \cup\left\{\rho_{k}(i, 2)\right\}_{k=1 . .2}
\end{gathered}
$$

The solving methods used require an initial value to be defined, represented by an initial vector:

$$
p_{0}=\left\{p_{0 k}\right\}_{k=1.2 n}=\left\{p_{0}(i, 1)\right\}_{k=1 . .2} \cup\left\{p_{0}(i, 2)\right\}_{k=1 . .2}
$$

The model was integrated in Matlab ${ }^{\circledR}$, and the resolution of the nonlinear system uses the existing function from the optimization toolbox. Six layers were finally considered and found to be representative for the DSF. The solver converged for this case with a computational time of less than 10 seconds.

The model is very sensitive to the coefficients linking the flows (in the left and right vertical channels and between the horizontal bands) and pressure 
differences between cells. To obtain the values of these coefficients, they were adjusted based on the experimental results obtained by Gavan et al. [19]. Initially, three coefficients $K_{b}, K_{a}, K_{i}$ were considered. These factors represent the permeability of the horizontal blinds, air channels and air inlet.

The determination of coefficients relied on some assumptions. The coefficient $K_{b}$ should vary depending on the angle of the blinds. The horizontal flow must be very low when the blinds are closed $\alpha=0^{\circ}$. At $\alpha=45^{\circ}$, it can also be considered that the flow in the left channel and the one in the right channel should be substantially equal. Thus, the ratio $K_{b} / K_{a}$ should vary from 0 to 1 depending on $\alpha$, with the value 0.5 for $\alpha=45^{\circ}$. In addition, the coefficients $K_{a}$ and $K_{i}$ should be approximately equal. The adjusted values of the pressure coefficients are presented in Table 1.

The pressure model determines the pressure field inside the double skin façade by imposing a mechanical flow and the air temperatures. It can also determine the values of the air flow in the double skin façade from the pressure field solution.

\subsection{Radiative heat transfer}

In a DSF, the natural convection and heat transfer play an important role. For building components, the radiative heat transfer can be divided into long-wave (LW) heat transfer and short-wave (SW) heat transfer. In the first stage, the SW heat flux absorbed by the various components of the façade is evaluated, and the net flux exchanged in LW is calculated. In this section, the SW and LW radiation heat transfers of the DSF model are studied. In the first part 2.2.1, information regarding the movement and 
the position of the sun are given. The form factors influencing the shortwave radiation heat transfer process are evaluated as well. Part 2.2.2 is then described.

\subsubsection{Heat flow absorbed by short-wave radiation}

Before calculating the flow, it is necessary to perform preliminary steps. First, the form factors of different components are calculated, and the direct solar flux through these components is determined. Finally, different SW irradiation received is established by taking into account the direct and diffuse solar irradiation.

Calculation of the form factors. The form factors represent the fraction of energy exchanged between the different facets of a surface domain. The form factor $F_{i j}$ represents the fraction of energy leaving the facet $i$ and received by the facet $j$. These factors depend only on geometry. To calculate these different factors, the method of Hottel [20] is used. The assumptions are as follows.

Assumption 1: the radiative exchanges are two-dimensional.

Assumption 2: the Venetian blinds are flat.

Assumption 3: the exchange surfaces of windows are represented by the facets 1 and 2 (see Figure 4).

This method is a 2D method that does not take into account the phenomena that occur on the edges of the double skin façade. In this method, it is assumed that the windows receive the same radiation as the vertical 
surfaces between the two strips. The interaction between the bands defined by 2 strips is neglected. One limitation of this method is the width of the air channel. In the case of a double skin façade with a wider channel, this method must be revised.

Calculation of the solar ratio. This ratio, known as $F_{\text {sol }}$, estimates the amount of direct solar radiation that passes through the horizontal blinds and enters the internal glazing surface directly. Therefore, $\left(1-F_{\text {sol }}\right)$ is the amount of radiation coming directly on the sunscreen. This ratio depends on the width of the blinds, the height and position of the sun. It is assumed that the Venetian blinds tilt angle varies from $0^{\circ}$ to $90^{\circ}$. It is also assumed that the relative azimuth is zero which implies that the double skin façade is facing south. The expression of the solar ratio is written as a function of $\alpha$ (angle of incidence of sunlight), $\beta$ (blind's angle) and $e$ (spacing between the Venetian blinds):

$$
F_{\text {sol }}=\frac{e-(a+b)}{e}
$$

Estimation of the heat flow absorbed at $S W$. In the following section, assessments of all four surfaces are carried out: upper blind $S_{L}$, lower blind $S_{S}$, internal glazing $S_{2}$ and external glazing $S_{1}$ (see Figure 5). The direct solar flux and the diffuse solar flux are taken into account, and the irradiance received by each surface is written as:

$$
E_{i, S W}=E_{i, S W}^{0}+\sum_{j=1}^{n} F_{i j} \rho_{j} E_{j, S W}
$$

where $E_{i, S W}^{0}$ represents the solar flux received directly without the multireflections and $\rho_{j}$ are the reflection factors, which leads to the following 
system:

$$
\left\{\begin{array}{c}
E_{1, S W}^{0}=0 \\
E_{2, S W}^{0}=F_{12} E_{\text {diffuse }}+F_{\text {sol }} E_{\text {direct }} \\
E_{S, S W}^{0}=\left(S_{1} / S_{S}\right) F_{1 S} E_{\text {diffuse }}+\left(S_{1} / S_{S}\right)\left(1-F_{\text {sol }}\right) E_{\text {direct }} \\
E_{L, S W}^{0}=\left(S_{1} / S_{S}\right) F_{1 L} E_{\text {diffuse }}
\end{array}\right.
$$

By solving the above system, access to the global irradiance at SW (directly received and due to multi-reflections) received by each of the 4 surfaces is possible.

\subsubsection{Heat flow absorbed at long wavelengths}

There is also a heat transfer between the glazing in LW, directly related to the temperature of the surface and the emissivity. The model uses the radiosity method and the form factors determined by Hottel's approach to determine the flows for LW radiation. Each radiosity is defined in terms of emittance of all surfaces. Then the net heat flux radiated by each surface is expressed, considering that each surface is gray and diffuse for the emission and the reflection. The net flow in LW radiation of each surface is determined by the radiation exchange balance between surfaces:

$$
\left\{\phi_{L W}^{n e t}\right\}=[M A T][h r]\left\{T-\overline{T_{s}}\right\}
$$

with

$$
\begin{gathered}
{[M A T]=[S][\varepsilon]\left[[[I]-[F][I-\varepsilon]]^{-1}[F][\varepsilon]\right]} \\
\{T\}=\left\{T_{s}\right\}_{s=1, b, 2} \\
h_{r_{i}}=\sigma_{0}\left(T_{i}^{2}+\overline{T_{s}^{2}}\right)\left(T_{i}+\overline{T_{s}}\right)
\end{gathered}
$$


where $\overline{T_{s}}$ is equal to $273.15 \mathrm{~K}$ and $\sigma_{0}$ is the Stefan-Boltzmann constant.

The model also takes into account the exchange in terms of the LW radiation with the outdoor (ground and sky) and the inner walls of the adjacent room. The double skin façade exchange in LW radiation with the sky and the ground and the radiative flux can be calculated using the formula:

$\phi_{L W, e x t}^{\text {net }}=\sigma_{0} \alpha_{L W} \frac{1+\cos \theta}{2}\left(T_{s k y}^{4}-T_{s, e x t}^{4}\right)+\sigma_{0} \alpha_{L W} \frac{1-\cos \theta}{2}\left(T_{\text {ground }}^{4}-T_{s, e x t}^{4}\right)$

where $\theta$ is the angle of the wall from the ground. In the case of a vertical double skin façade, $\theta=90^{\circ}$, and, therefore, the second term disappears. The coefficient $h_{r c}$ is used:

$$
h_{r c}=\sigma_{0}\left(T_{s k y}+T_{s, e x t}\right)\left(T_{s k y}^{2}+T_{s, e x t}^{2}\right)
$$

The values of $h_{r c}$ are in a small range for temperatures usually encountered in the building, so a constant value of $h_{r c}=5 \mathrm{Wm}^{-2} \mathrm{~K}^{-1}$ can be assumed.

$$
\phi_{L W, e x t}^{n e t}=\alpha_{L W} h_{r c}\left(T_{s k y}-T_{s, e x t}\right)
$$

\subsection{Convection transfer modelling}

In DSFs, a convective heat transfer occurs at each air-wall interface. Six convective flows can be distinguished in the double skin façade, which require convection heat transfer coefficients. The six convective flows are outdoor air/external glazing, external glazing/left channel, left channel/blinds, blinds/right channel, right channel/internal glazing and internal glazing/indoor air (see Figure 6). It is assumed that the convective heat transfer coefficients 
are constant over the height of the double skin façade and do not vary much depending on the inclination of the Venetian blinds (further information can be found in [11]). For the calculation of the $h_{c 1}, h_{c 2}, h_{c 3}, h_{c 4}$, the calculation of the Nusselt number is used [20]. Regarding the convective heat transfer coefficient between the outdoor air and the air inside the room, the model uses values proposed by the actual French Thermal Regulation [21].

\subsection{Thermal energy balance}

The time constant of the heat transfer process due to heat flow is much lower than the time constant of the building. Thus, the transient process is assumed to be a succession of steady states. For each surface element $(i, s)$, a heat energy balance is performed by taking into account the radiative transfer and the convective transfer:

$$
\begin{gathered}
\text { ent }(i, 1)=\sum_{\text {inlet flows }}\left[\rho_{i, 1, \text { inlet }} c_{\text {air }} Q_{i, 1, \text { inlet }} T_{i, 1, \text { inlet }}\right]-\sum_{\text {outlet flows }}\left[\rho_{\text {air }}(i, 1) c_{\text {air }} Q_{i, 1, \text { outlet }} T_{\text {air }}(i, 1)\right] \\
+h_{c 1} S\left(T_{1}(i)-T_{\text {air }}(i, 1)\right)+h_{c 2} S\left(T_{b}(i)-T_{\text {air }}(i, 1)\right)
\end{gathered}
$$

where $Q_{i, 1, \text { inlet }}$ is the air flow coming from an adjacent cell and entering the cell $i$ of the left channel, $\rho_{i, 1, \text { inlet }}$ is the mass density of air entering the cell $i$ of the left channel, $T_{i, 1, i n l e t}$ is the air temperature entering the cell $i$ of the left channel, $c_{\text {air }}$ is the specific heat of air, $Q_{i, 1, \text { outlet }}$ is the outlet flow from cell $i, \rho_{\text {air }}(i, 1)$ is the air density in cell $i, T_{\text {air }}(i, 1)$ is the air temperature in the left channel of the cell $i, T_{1}(i)$ is the temperature of the external glass the band $i, T_{b}(i)$ is the Venetian blind temperature of cell $i$ and $S$ is the amount of area of convective heat transfer $S=e l$, where $l$ is the width of 
the double skin façade and $e$ is the height of a cell. Similarly, the enthalpy balance for the cell $i$ of the right channel is:

$$
\begin{gathered}
\text { ent }(i, 2)=\sum_{\text {inlet flows }}\left[\rho_{i, 2, \text { inlet }} c_{\text {air }} Q_{i, 2, \text { inlet }} T_{i, 2, \text { inlet }}\right]-\sum_{\text {outlet flows }}\left[\rho_{\text {air }}(i, 2) c_{\text {air }} Q_{i, 2, \text { outlet }} T_{\text {air }}(i, 2)\right] \\
+h_{c 3} S\left(T_{b}(i)-T_{\text {air }}(i, 2)\right)+h_{c 4} S\left(T_{2}(i)-T_{\text {air }}(i, 2)\right)
\end{gathered}
$$

For each cell $i$, the thermal energy balance of radiative and convective heat transfer for the three surfaces (interior glazing, Venetian blinds, external glazing) is written. As an example for the external glazing, the following phenomena are observed:

- On the external face (direct and diffuse irradiation at short wavelengths, radiative heat flux exchanged with the ground and sky, convective heat exchange with the air)

- On the left channel face (heat flux absorbed in short wavelength, net heat flux at long wavelengths, convective flow exchanged with the air of the left channel)

$$
\begin{gathered}
\text { th }(i, \text { int })=\alpha_{1} S\left(E_{\text {dif }}+E_{\text {dir }}\right)+h_{c_{\text {ground }}} S\left(T_{\text {ground }}-T_{1}(i)\right)+h_{c_{\text {ext }}} S\left(T_{\text {ext }}-T_{1}(i)\right)+ \\
\alpha_{1} S E_{1, S W}-\Phi_{\text {net }, L W, D S F}+h_{c 1} S\left(T_{\text {air }}(i, 1)-T_{1}(i)\right)
\end{gathered}
$$

The global model is solved iteratively in 2 phases. The first phase is the determination of flows within the DSF from the model of mass transfer. In this phase, the model uses the initial temperatures of the air and surface of the DSF at the first iteration and then given by the second phase during the following iterations. The second phase is the calculation of the temperatures 
of air and surface from the system resolution resulting from energy balances. For this stage, the model is applied using the flows inside the double skin façade given in the first step. The resolution stops when the differences between the temperatures obtained during two consecutive cycles are below a chosen value. The model algorithm is presented in Figure 7.

\section{Full-scale experiment}

The main problem with simplified models is to validate them with accurate experimental data. A full-scale experiment was developed for this purpose, and the aim of this section is to describe this unique test cell experiment. More information about these experiments are given in [19].

\subsection{Description of the test cell}

To study and validate the numerical model proposed, detailed experimental data must be obtained. The reliability of different measurements can only be acquired in a controllable experimental environment in terms of solar irradiation, air temperature or air flow. A double skin façade was installed in the laboratory and was integrated with a test cell called MINIBAT.

The experimental cell MINIBAT presented in Figure 8 is composed of two identical enclosures (Cell 1 and Cell 2), whose dimensions are 3.10m, 3.10m and $2.50 \mathrm{~m}$ according to the coordinate directions $(x, y, z)$. A double glazed façade isolates Cell 1 from a climatic chamber where the air temperature is controlled by means of an air-treatment system. The climatic chamber temperature can vary between $-10^{\circ} \mathrm{C}$ and $40^{\circ} \mathrm{C}$ as a function of time. Using a battery of 12 spotlights, of $1000 \mathrm{~W}$ each, it is possible to simulate an artificial 
sunning for Cell 1. The spectrum of the gas discharge lamps with metal halide is similar to the sun.

The double skin façade, presented in Figure 9, is made of two aluminium frames: external and internal. The internal is composed of one fixed part $(W \times H=2.8 m \times 2.3 m)$, and the external one is divided into two parts that can be separately opened. The glass panels separated by the $20 \mathrm{~cm}$ of air volume are two simple clear glazing (without a surface treatment). The glass area is $W \times H=(2 \times 1.3 m) \times 1.93 m$ for the external pane and $W \times H=2.8 m \times 1.93 m$ for the internal pane.

Four openings are included in the DSF with dimensions of $W \times H=$ $2.6 m \times 0.04 m$ each. Using these openings in the upper and bottom part of the façade, different ventilation configurations can be tested by simple obstruction of these inflow spaces. As shading devices used in the experiment, Venetian blinds were installed for the most commonly used case for such a façade. The angle of the blinds can be oriented automatically during the tests from the exterior of the façade (mechanical orientation device).

The Venetian blades installed in the DSF are made of aluminium, were $2.5 \mathrm{~cm}$ in width and $0.21 \mathrm{~mm}$ in thickness, and the chosen color was yellow gloss. The DSF is exposed to the controlled climatic conditions, and an accurate airflow control of air supply system was build to vary different air flow rates.

\subsection{Metrology}

The DSF airflow measurement system is composed of two differential pressure devices (two blades, thus limiting the differential heads and turbulences) and a sensor box with the differential pressure elements. These two pressure 
elements have a distribution of apertures on the airfoil permitting the control of the average airflow (by averaging the differential pressures). The pressure transmitters working with a differential probe are configured with a square root function. Via this function, and from the differential pressure, the transmitter calculates airflow rate in the duct, and thus in the DSF. The accuracy of the airflow measurement device is $\pm 0.5 \%$ of the measurement.

The DSF itself is instrumented using thermocouples, distributed on all the elements of the DSF. Type-T thermocouples with flattened joint are used here for a better contact with the glass surface. Among these sensors, 15 thermocouples are affected for the glass surface temperatures and 10 for air temperatures. All the thermocouples installed in the DSF are shielded to the solar simulator radiation using a special paint. This paint is Labsphere Spectraflect. The measured accuracy, taking into account the solar radiation effects, is $\pm 1^{\circ} \mathrm{C}$.

\subsection{Experimental protocol}

Every test consists in setting up parameters of the test cell facility (boundary conditions) and DSF. Simultaneously, the solar simulator is switched on and synchronized with the acquisition system. The time delay between two measurements is $300 \mathrm{~s}$ (i.e. a measurement frequency of $0.003 \mathrm{~Hz}$ ). The test cell reaches the steady state condition after $48 h$ when the DSF is ventilated, respectively, $72 h$ with no airflow in the DSF. All the values presented in this paper were obtained averaging 100 values recorded at steady state. During the tests, the air temperature inside the weather generator was fixed at $32^{\circ} \mathrm{C}$. 


\section{Numerical validation}

This section is dedicated to a comparison between experimental data and numerical results. For the completely closed blinds $\left(90^{\circ}\right)$, because the theoretical transmittance is equal to 0 , the first consequence is that no radiation will enter the cell. However, with multiple reflections and solar radiation leakage regions of the façade, the average radiation passing through the test cell was found to be around $20 \mathrm{Wm}^{-2}$. Table 2 resumes the thermo-physical proprieties of the external pane, the Venetian blades and internal pane (transmissivity, absorptivity and reflectivity).

Different cases were studied with different airflows combined with different tilt angles of the shading devices. For these cases, the angle of the Venetian blinds can vary between $0^{\circ}$ (completely opened blinds) and $90^{\circ}$ (completely closed blinds). The airflow range varies between 0 and $600 \mathrm{~m}^{3} \mathrm{~h}^{-1}$, corresponding to $0-193 m^{3} h^{-1}$ for one meter of façade.

The external conditions of temperature and irradiance are set to the ones during the experimental campaign. Thus, the comparison is significant and allows the validation of the global model of the DSF. The uncertainty of the shielded temperature probes is $\pm 1^{\circ} \mathrm{C}$.

Two experimental measurements were studied, one taken in the bottom part of the double skin façade and the other one taken in the upper part. The numerical model gives six temperature measurements on the DSF height. There is a general increase in temperature with the height. In all cases, the upper part of the double skin façade is warmer than the bottom. The results were analyzed for different air flows, 0, 200, 400 and $600 \mathrm{~m}^{3} \mathrm{~h}^{-1}$, and, for 
each flow, five values of blades tilt angle $\alpha, 0^{\circ}, 30^{\circ}, 45^{\circ}, 60^{\circ}, 90^{\circ}$, were used.

The results of the numerical model are compared with the experimental data as shown in Figures 10, 11 and 12 in terms of the air temperature in the left/right channel and the temperature of the Venetian blades. For an air flow of $400 m^{3} h^{-1}$ in the DSF, the theoretical results are very close to the values obtained by experimentation, excepting for $\alpha=90^{\circ}$. The difference between the numerical modeling and the experimental data, taking into account the uncertainty of measurement, never exceeds $0.5^{\circ} \mathrm{C}$.

In Figure 10, the theoretical temperature of the air in the left channel is close to the experimental value in the upper part of the DSF. For the bottom, a difference can be observed. The air injected into the channel is at a temperature of $31.5^{\circ} \mathrm{C}$, and it seems surprising that the air flow through the channel is at $34.6^{\circ} \mathrm{C}$ only a few centimeters from the inlet, so there is doubt as to the reliability or the position of this measurement. In Figure 13, the temperature of the shading devices increases until $\alpha=45^{\circ}$, then decreases for higher tilt angles.

For $\alpha=0^{\circ}$, the angle of incidence is low and the blades receive a small amount of irradiation radiation at short wavelengths. For $\alpha=45^{\circ}$, the blades receive a higher amount of irradiation and also have the benefit of multi-reflections. For $\alpha=90^{\circ}$, the blades are closed, and all direct radiation is received, but some part of the radiation is reflected directly to the external face of the DSF, which explains the temperature decrease. The temperature inside the glass decreases fairly regularly when the tilt angles increases. 


\section{First observations}

There is less direct short wavelength illumination received by the inner pane, which implies the significant role played by irradiation on the temperature of this element. The temperature of the exterior glazing increases when the tilt angles increases. The influence of the inclination of the blades is less important for the exterior glazing than for the internal glazing. The increase in the temperature of the external pane is linked to the multi-reflections. Among the three temperatures analyzed in Figure 13, the temperature of the inner pane shows the most important variations. This element of the double skin façade is therefore particularly sensitive to the management of the angle of the inclination of the blades.

The model results were compared to the experimental data on the width of the double skin façade for different positions of the $x$-axis (Table 3 ). The positions considered were $x_{1}=0 m$ (external glazing), $x_{2}=0.05 m$ (left channel), $x_{3}=0.1 \mathrm{~m}$ (Venetian blinds), $x_{4}=0.15 \mathrm{~m}$ (right channel) and $x_{5}=0.2 \mathrm{~m}$ (interior glazing).

In the case of the model results, as in the experiment (see Table 3), the Venetian blades have the highest temperature of all elements, regardless of tilt angle and ventilation rate, except in the case of $\alpha=0^{\circ}$. In this configuration, the shading devices capture less direct solar irradiance. These surfaces have the highest temperature, especially if the ventilation rate is not important.

For the closed position $\left(\alpha=90^{\circ}\right)$ of the blades, a very low temperature value of the internal glazing is observed. Indeed, in this configuration, the inner pane, in the case of the numerical model, does not receive any radiation 
from outdoor; it exchanges only radiation with the interior of the room. The difference between the model and the experiment may signify that the interior is receiving a certain amount of irradiance. Furthermore, the model estimates the radiation exchange with the interior of the piece based on strong assumptions on our part.

The measure of the temperatures of the walls inside the test cell could give more certainty in these exchanges. However, the slight differences observed the temperature curves are close, and the model results seemed to be within the area of uncertainty of the experimental measurements.

One of the problems of double skin façades is to satisfy the need for summer comfort, so it is interesting to look at the temperature drop achievable through effective management of the shading and ventilation of the double skin façade. The management of these two design parameters has an important impact on the indoor conditions and the level of daylight.

When taking into account energy gains of the double skin façade, it is also interesting to know the cost of the mechanical ventilation of the DSF compared to several sides in terms of electricity bill for artificial lighting or the use of an air conditioning system.

The study of the indoor glazing temperature can give interesting insights into the control of the two parameters (air flow and tilt angle of the blades). There seems to be a great interest in using mechanical ventilation relative to natural ventilation. The gain in temperature for the inner pane between natural ventilation and mechanical ventilation with an air flow of $200 \mathrm{~m}^{3} h^{-1}$ varies between $1.8^{\circ} \mathrm{C}$ for $\alpha=0^{\circ}$ and $3.8^{\circ} \mathrm{C}$ for $\alpha=90^{\circ}$. The mean air drop temperature may be considered to be around $2^{\circ} \mathrm{C}$. 
It also seems interesting to use a flow of $400 \mathrm{~m}^{3} h^{-1}$ rather than using $200 m^{3} h^{-1}$ because the decrease in temperature on the inner pane is about $1.1^{\circ} \mathrm{C}$ to $1.2^{\circ} \mathrm{C}$, values which could have an impact on the thermal comfort amelioration. However, it seems less interesting to increase the ventilation rate from $400 \mathrm{~m}^{3} \mathrm{~h}^{-1}$ to higher values because only a $0.7^{\circ} \mathrm{C}$ difference was noticed. The inner pane goes from a temperature of $40.6^{\circ} \mathrm{C}$, for $\alpha=0^{\circ}$ in natural ventilation, to $32.4^{\circ} \mathrm{C}$ for $\alpha=90^{\circ}$ and $D=600 m^{3} h^{-1}$, which represents a gain of $8.2^{\circ} \mathrm{C}$ on the surface of the glazing with high impact on the indoor climate. This study therefore shows that it is important to optimize the use of ventilation and shading in a double skin façade.

\section{Conclusions}

A numerical modelling of a DSF has been developed in this paper, based on a zonal model approach. This model includes convective, radiative and aeraulic heat transfers. A full scale DSF has been monitored to test different configurations of airflow rates and blades angles. The first result of our study is the validation of the numerical modelling using the experimental data.

The results were analysed to determine management regulations for both parameters studied (Venetian blind angle and ventilation rate) to obtain a temperature of the interior glazing within the lowest possible value. Even for the complex behaviour of the DSF, the numerical model could optimize the two parameters, and optimal conditions of functioning could be attained. A more comprehensive approach should also consider the energy cost of ventilation and the cost of artificial lighting if necessary.

The next step of our work will be to analyze the coupling between the DSF 
numerical modelling developed in the present paper and an office building numerical modelling. The final objective is to optimize the control of the DSF.

\section{References}

\section{References}

[1] M. Shameri, M. Alghoul, K. Sopian, M. F. M. Zain, O. Elayeb, Perspectives of double skin façade systems in buildings and energy saving, Renewable and Sustainable Energy Reviews 15 (3) (2011) 1468 - 1475.

[2] J. S. Carlos, H. Corvacho, P. D. Silva, J. Castro-Gomes, Modelling and simulation of a ventilated double window, Applied Thermal Engineering 31 (1) (2011) $93-102$.

[3] N. Hashemi, R. Fayaz, M. Sarshar, Thermal behaviour of a ventilated double skin façade in hot arid climate, Energy and Buildings 42 (10) (2010) $1823-1832$.

[4] L. Xu, T. Ojima, Field experiments on natural energy utilization in a residential house with a double skin façade system, Building and Environment $42(5)(2007) 2014-2023$.

[5] H. Poizaris, Double skin façade a litterature review. Report of IEA SHC TASK 34 ECBCS ANNEX 43, Tech. rep., Department of Architecture and Built Environment, Division of Energy and Building Design. Lund University, Lund Institute of Technology, Sweden. (2006). 
[6] I. Perez-Grande, J. Meseguer, G. Alonso, Influence of glass properties on the performance of double-glazed façades, Applied Thermal Engineering 25 (17-18) (2005) 3163 - 3175.

[7] N. Hamza, C. Underwood, CFD supported modelling of double skin façades in hot arid climates, in: Ninth International IBPSA Conference, Montreal, Canada, August 15-18, 2005, pp. 365-372.

[8] E. Gratia, A. D. Herde, Optimal operation of a south double-skin façade, Energy and Buildings 36 (1) (2004) $41-60$.

[9] C. S. Park, G. Augenbroe, M. Thitisiwat, Integrated control strategied for double skin systems, in: Ninth International IBPSA Conference, Montreal, Canada, August 15-18, 2005, pp. 929-936.

[10] N. Safer, M. Woloszyn, J. J. Roux, G. Rusaouen, F. Kuznik, Modelling the double skin façades for building energy simulations: radiative and convective heat transfer, in: Ninth International IBPSA Conference, Montreal, Canada, August 15-18, 2005, pp. 1067-1074.

[11] N. Safer, M. Woloszyn, J. J. Roux, Three-dimensional simulation with a CFD tool of the airflow phenomena in single floor double-skin façade equipped with a venetian blind, Solar Energy 79 (2) (2005) 193 - 203.

[12] C. Balocco, M. Colombari, Thermal behaviour of interactive mechanically ventilated double glazed façade: Non-dimensional analysis, Energy and Buildings 38 (1) (2006) $1-7$. 
[13] C.-S. Park, G. Augenbroe, T. Messadi, M. Thitisawat, N. Sadegh, Calibration of a lumped simulation model for double-skin façade systems, Energy and Buildings 36 (11) (2004) 1117 - 1130.

[14] G. Gan, Thermal transmittance of multiple glazing: computational fluid dynamics prediction, Applied Thermal Engineering 21 (15) (2001) 1583 -1592 .

[15] H. Manz, T. Frank, Thermal simulation of buildings with double-skin façades, Energy and Buildings 37 (11) (2005) $1114-1121$, research That Inspires 125 Years of EMPA.

[16] D. Saelens, Energy performance assessment of single storey multiple-skin façades, Ph.D. thesis, Katholieke Universiteit Leuven (2002).

[17] T. E. Jiru, F. Haghighat, Modeling ventilated double skin façade-a zonal approach, Energy and Buildings 40 (8) (2008) 1567 - 1576.

[18] W. J. Stec, A. H. C. V. Paassen, Defining the performance of the double skin façade with the use of the simulation model, in: Eight International IBPSA Conference, Eindhoven, Netherlands, August 11-14, 2003, pp. $1243-1250$.

[19] V. Gavan, M. Woloszyn, F. Kuznik, J.-J. Roux, Experimental study of a mechanically ventilated double-skin façade with venetian sun-shading device: A full-scale investigation in controlled environment, Solar Energy 84 (2) (2010) $183-195$.

[20] N. Safer, Numerical modelling of double skin façades equipped with solar screens - Multiscale approach (in french), Ph.D. thesis, Centre de 
Thermique de Lyon, département de génie civil et urbanisme INSA de Lyon. France (2006).

[21] The French Thermal Regulation 2005 - French Ministry of Sustainable Development, France (2005).

[22] A. P. Faist, The double skin façade (in french), Tech. rep., Report of the Ecole Polytechnique Federal (EPF) de Lausanne, Lausanne, Switzerland (1998). 


\section{List of Tables}

1 Model coefficients in pressure depending on the angle of inclination of the blinds. . . . . . . . . . . . . . . . . 29

2 Double skin façade properties. . . . . . . . . . . . . 30

3 Air temperature in the DSF for different positions on the $\mathrm{x}$ axis $-400 m^{3} h^{-1}$. . . . . . . . . . . . . . 31

4 Inner glazing temperature drop for different air flows in the DSF. . . . . . . . . . . . . . . 32 


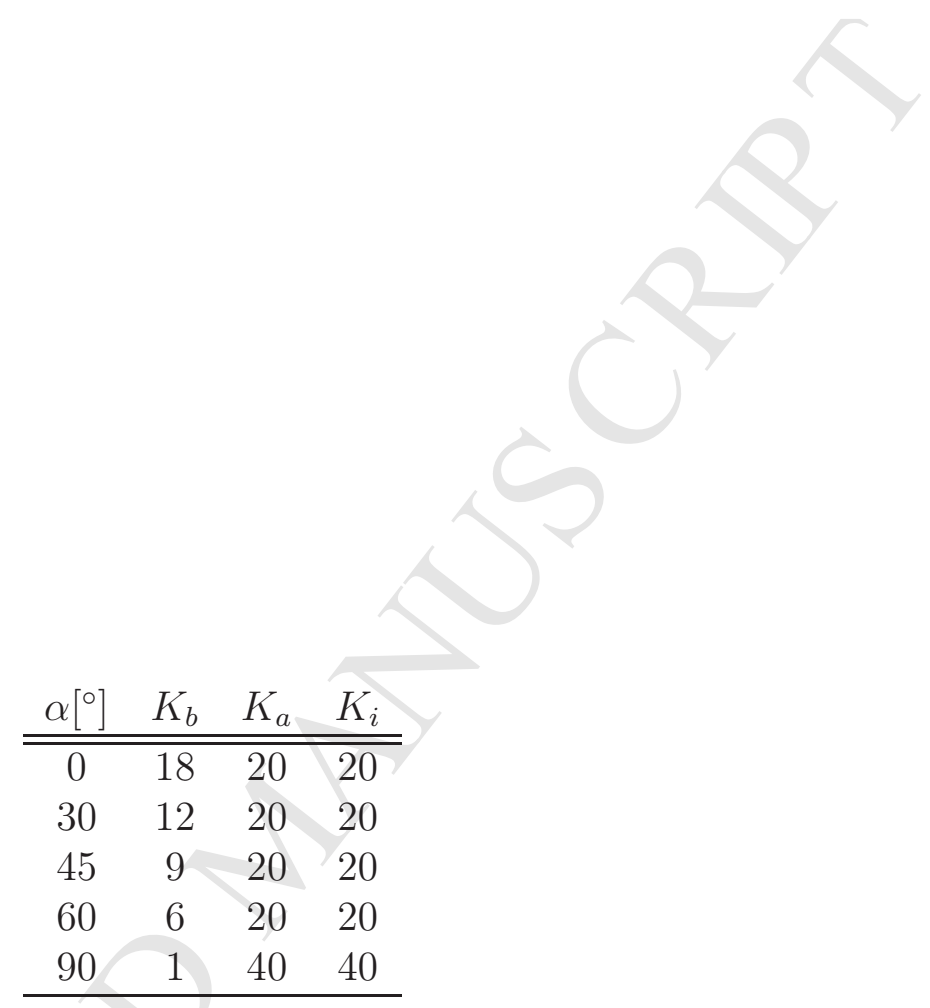

Table 1: Model coefficients in pressure depending on the angle of inclination of the blinds. 


\begin{tabular}{lcccc}
\hline \multirow{2}{*}{ layer } & \multicolumn{2}{c}{ dimensions } & transmissivity & absorptivity \\
\cline { 2 - 3 } & width $[\mathrm{m}]$ & height $[\mathrm{m}]$ & & \\
\hline \hline external DSF glass pane & 2.6 & 2.3 & 0.82 & 0.11 \\
Venetian blade & 2.6 & - & 0 & 0.1 \\
internal DSF glass pane & 2.6 & 2.3 & 0.82 & 0.11 \\
\hline
\end{tabular}

Table 2: Double skin façade properties. 


\begin{tabular}{ccccccc}
\hline DSF width $[m]$ & \multicolumn{2}{c}{$\mathbf{0}$} & $\mathbf{0 . 0 5}$ & $\mathbf{0 . 1}$ & $\mathbf{0 . 1 5}$ & $\mathbf{0 . 2}$ \\
& ext. & left ch. & blades & right ch. & int \\
& 0 & 36.2 & 36.3 & 38.2 & 37.2 & 39.1 \\
Model & 30 & 37.0 & 37.1 & 40.1 & 37.7 & 38.1 \\
results & 45 & 37.3 & 37.1 & 40.4 & 37.5 & 37.3 \\
& 60 & 37.5 & 36.9 & 40.1 & 37.2 & 36.3 \\
& 90 & 37.7 & 35.8 & 38.6 & 36.3 & 34.3 \\
\hline & 0 & 37.5 & 36.2 & 37.9 & 36.8 & 39.3 \\
Experimental & 30 & 38.2 & 37.2 & 40.5 & 36.6 & 37.8 \\
data & 45 & 38.4 & 373 & 40.7 & 36.6 & 37.6 \\
& 60 & 38.8 & 37.4 & 41.3 & 36.1 & 36.8 \\
& 90 & 39.1 & 37.4 & 41.2 & 36.1 & 36.4 \\
\hline
\end{tabular}

Table 3: Air temperature in the DSF for different positions on the x-axis - $400 m^{3} h^{-1}$. 


\begin{tabular}{cccccccc}
\hline angle $\left[^{\circ}\right]$ & $0 m^{3} h$ & $200 m^{3} h$ & difference & $400 m^{3} h$ & difference & $600 m^{3} h$ & difference \\
\hline \hline 0 & 40.5 & 38.7 & 1.8 & 37.6 & 1.1 & 36.9 & 0.7 \\
30 & 39.8 & 37.7 & 2.1 & 36.5 & 1.2 & 35.7 & 0.8 \\
45 & 39.0 & 36.9 & 2.1 & 35.7 & 1.2 & 34.9 & 0.8 \\
60 & 38.0 & 36.0 & 2.0 & 34.8 & 1.1 & 34.1 & 0.7 \\
90 & 37.7 & 33.8 & 3.8 & 33.2 & 0.6 & 32.6 & 0.6 \\
\hline
\end{tabular}

Table 4: Inner glazing temperature drop for different air flows in the DSF. 


\section{List of Figures}

1 Schematic diagram of a double skin façade according to Faist [22]. 34

2 Isotherm zone in a DSF predicted by CFD - Extracted from [20]. 35

3 Double skin façade layers discretization and variables. . . . . 36

4 Hottel method applied to the double skin façade: $e=0.025 \mathrm{~m}$ spacing between the blinds, $l=0.025 \mathrm{~m}$ blind's width and $\beta$ blind's angle. . . . . . . . . . . . . . 37

5 Schematic of different surfaces considered for the calculation of the irradiation in short wavelength. . . . . . . . . . 38

6 Convection coefficients of various air-surface interfaces of the DSF. . . . . . . . . . . . . . . 39

7 Model resolution algorithm. . . . . . . . . . . . . . 40

8 Test cell facility scheme: 1, cooling unit; 2, weather generator; 3 , double skin façade; 4 , protection glass of the solar simulator; 5, test cell; 6, concrete; 7, air blowing plenum; 8, solar simulator's heat removal ventilators; 9 , air extraction plenum; 10, HVAC unit of the buffer zone; 11, solar simulator; 12, controlled buffer zone. (Metric units) [16]. . . . . . . . . . . . 41

9 DSF section view: 1, $6 \mathrm{~mm}$ glass layer; 2, solar protections; 3 , metallic support; 4 , solar protection action box; 5 , concrete beam; 6, aluminum frame; 7, pane opening articulation; 8, ventilation openings. (Metric units) [16]. . . . . . . . . . . . 42

10 Air temperature profile in the left channel of the DSF for an airflow equal to $400 \mathrm{~m}^{3} h^{-1}$ - circle: experimental data and line: numerical modelling. . . . . . . . . . . . . . . . . . . . 43

11 Air temperature profile in the right channel of the DSF for an airflow equal to $400 \mathrm{~m}^{3} h^{-1}$ - circle: experimental data and line: numerical modelling. . . . . . . . . . . . . . . . . . 44

12 Venetian blades temperature for an airflow equal to $400 m^{3} h^{-1}$ - circle: experimental data and line: numerical modelling. . . . 45

13 Temperature variation in the DSF for different air flows and blades tilt angles - Numerical modelling. . . . . . . . . . . . . 46 


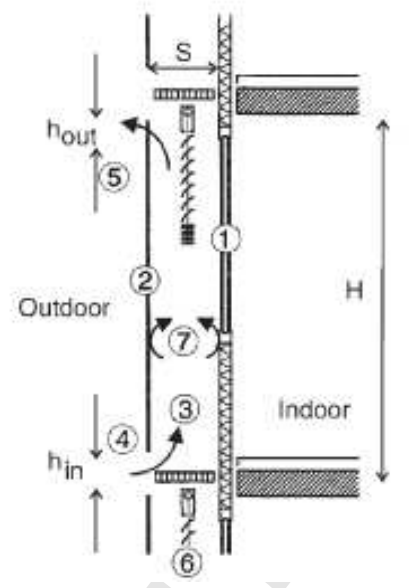

(1) Internal facade

(2) External facade

(3) Air gap

(4) Air inlet grating (in)

(5) Air outlet grating (out)

(6) Shading device

(7) Mean average heat transfer coefficients

Figure 1: Schematic diagram of a double skin façade according to Faist [22].

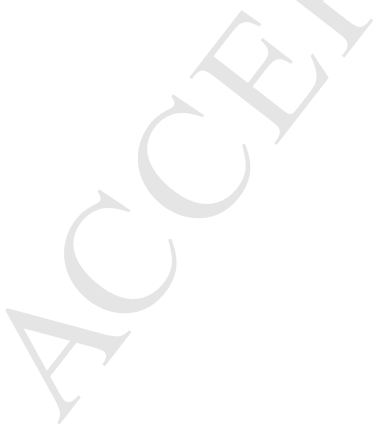



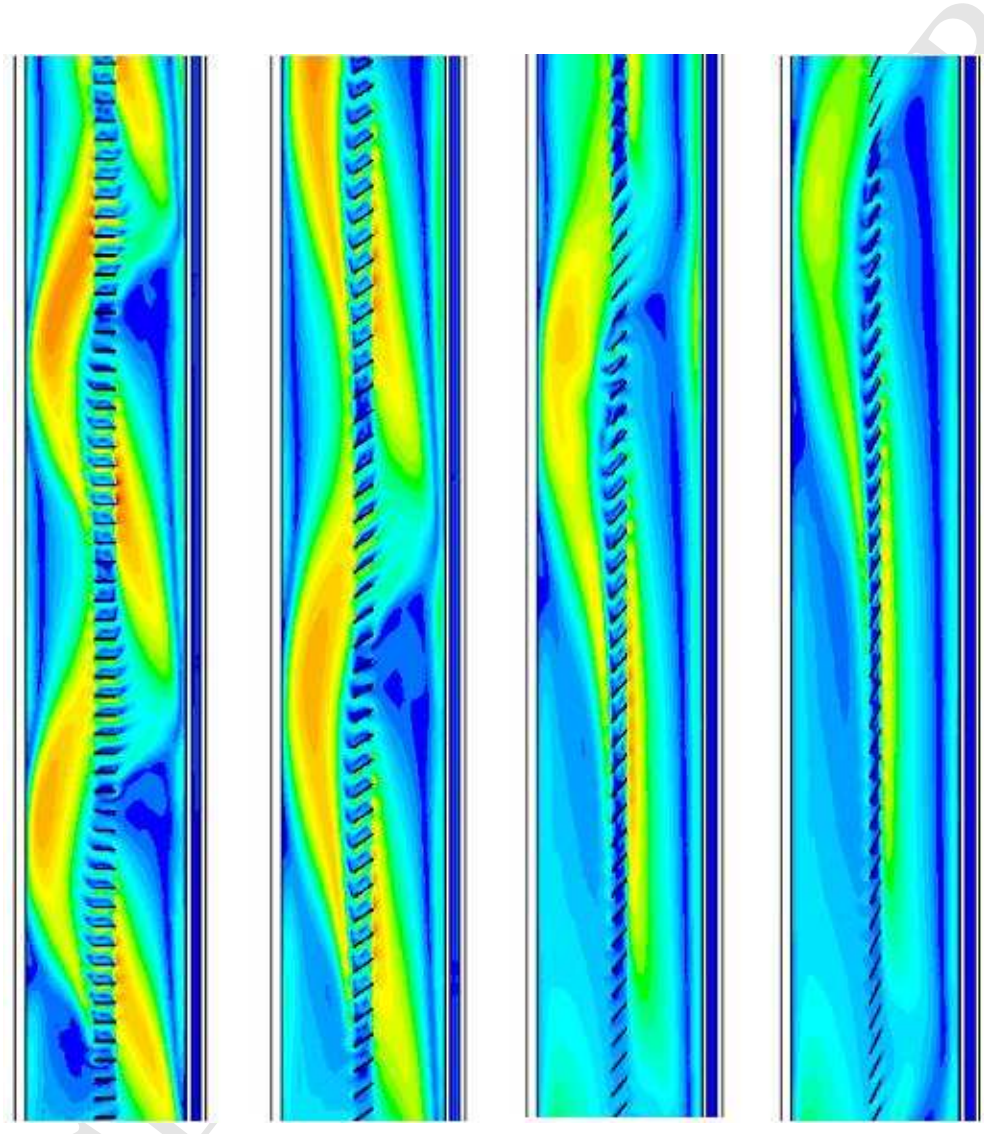

Figure 2: Isotherm zone in a DSF predicted by CFD - Extracted from [20]. 


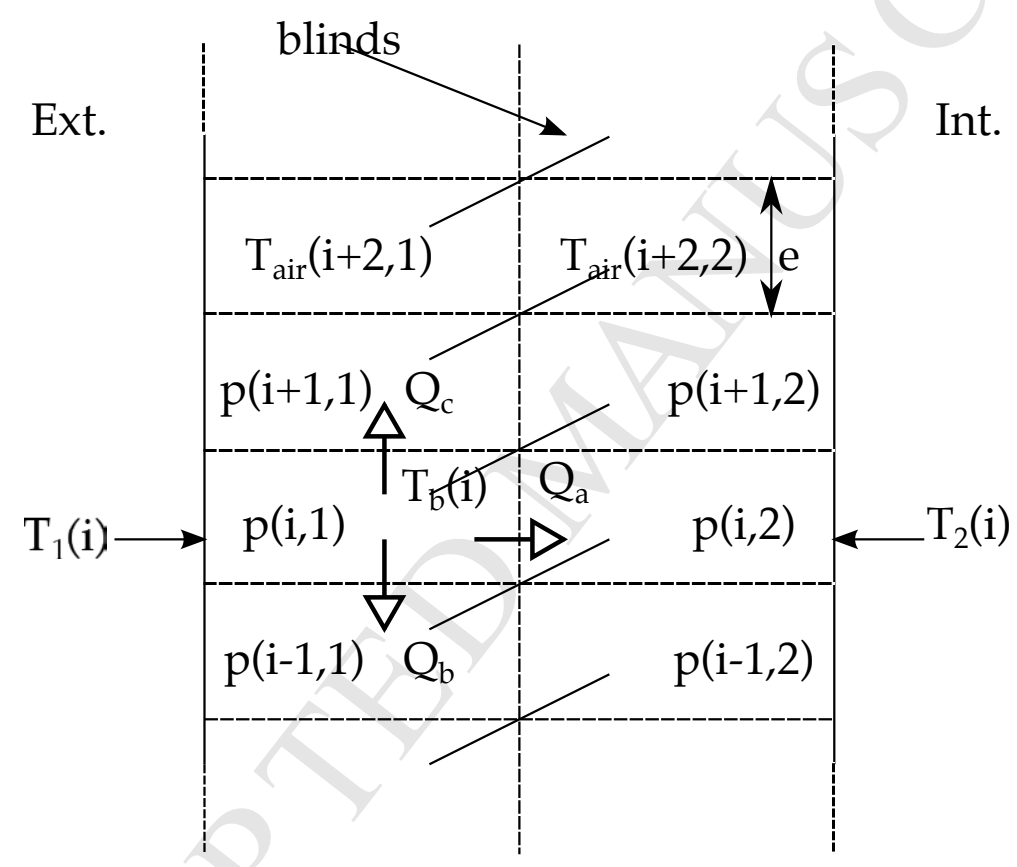

Figure 3: Double skin façade layers discretization and variables. 


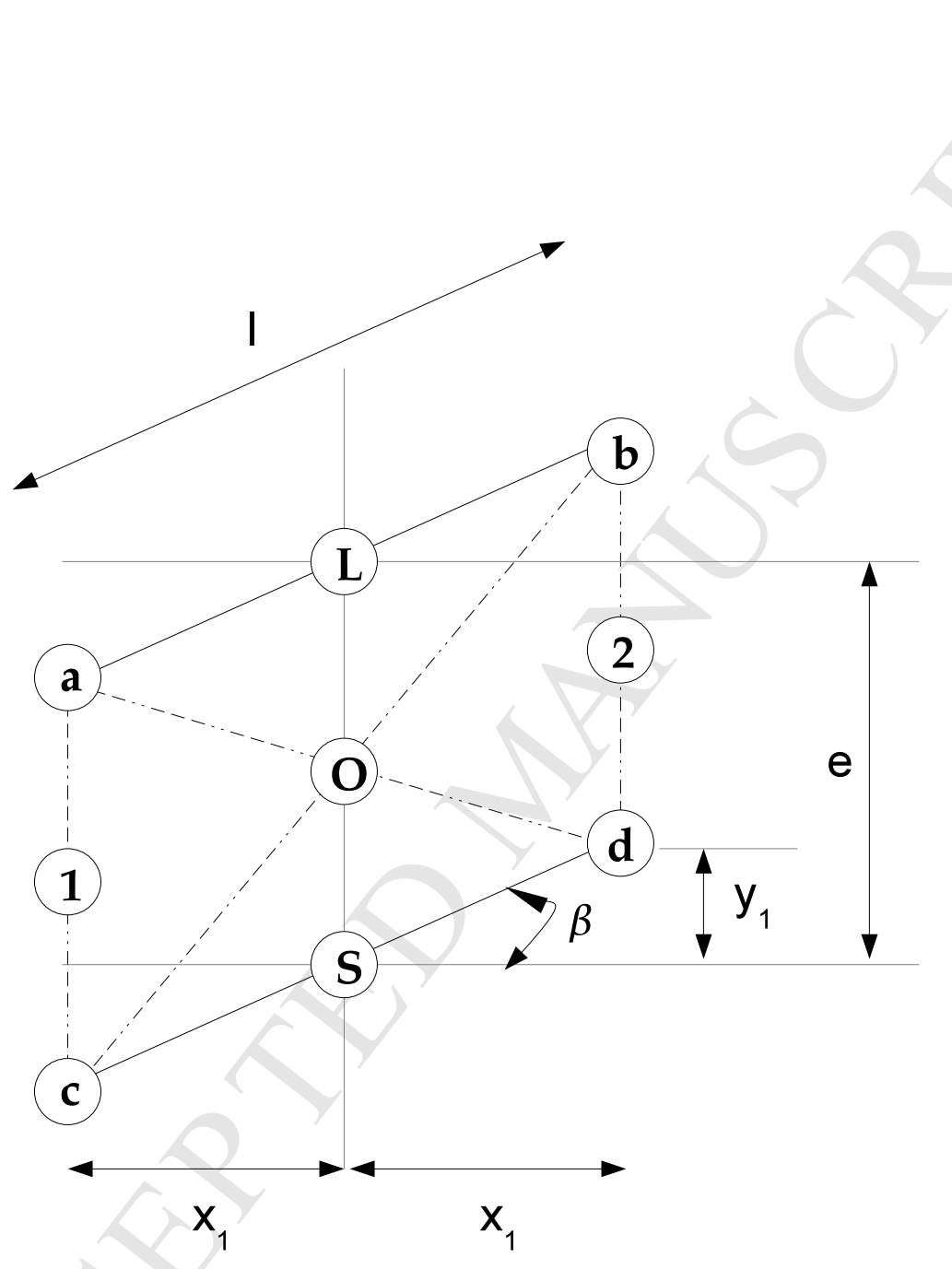

Figure 4: Hottel method applied to the double skin façade: $e=0.025 \mathrm{~m}$ spacing between the blinds, $l=0.025 \mathrm{~m}$ blind's width and $\beta$ blind's angle. 


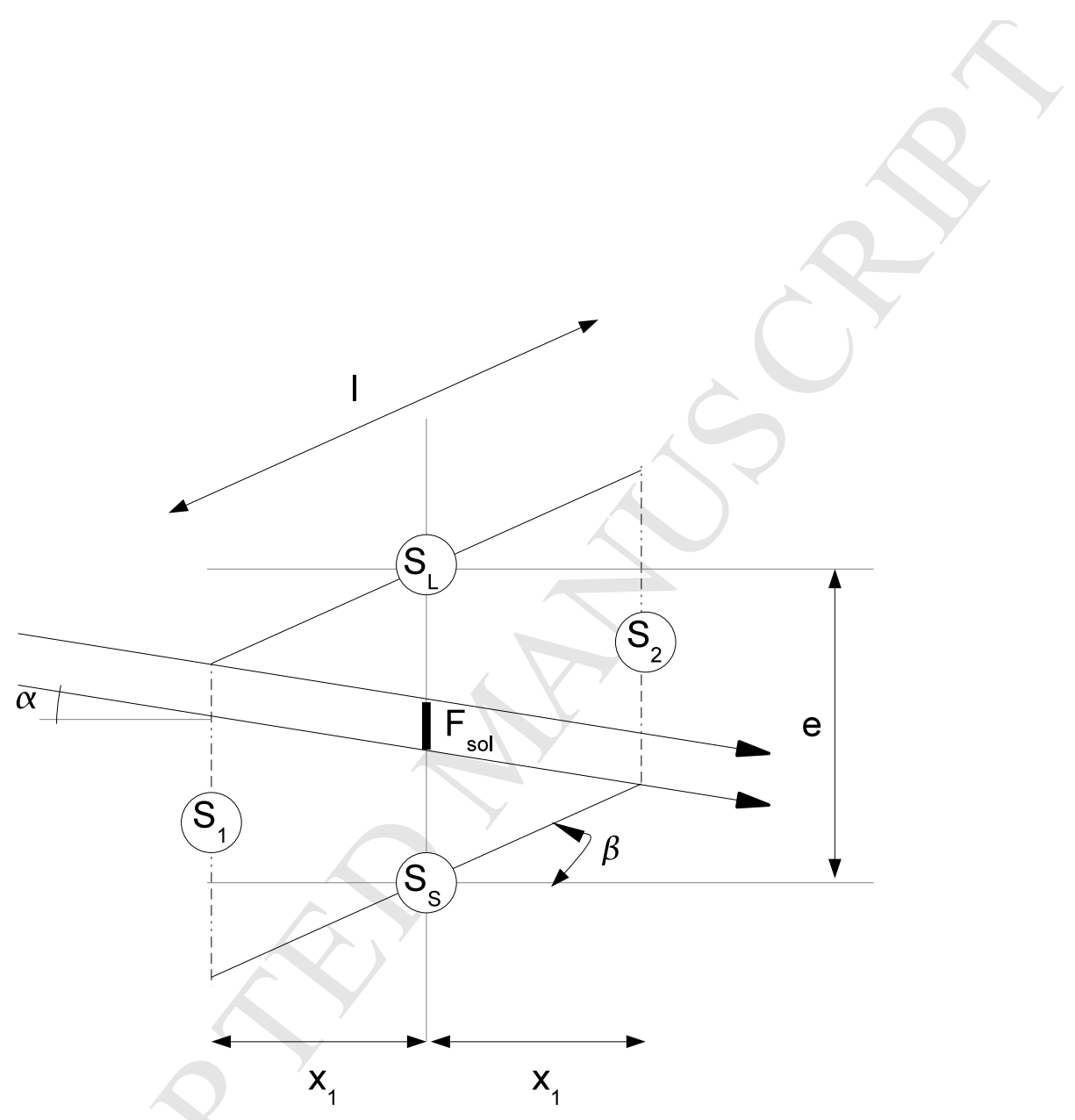

Figure 5: Schematic of different surfaces considered for the calculation of the irradiation in short wavelength. 




Figure 6: Convection coefficients of various air-surface interfaces of the DSF. 


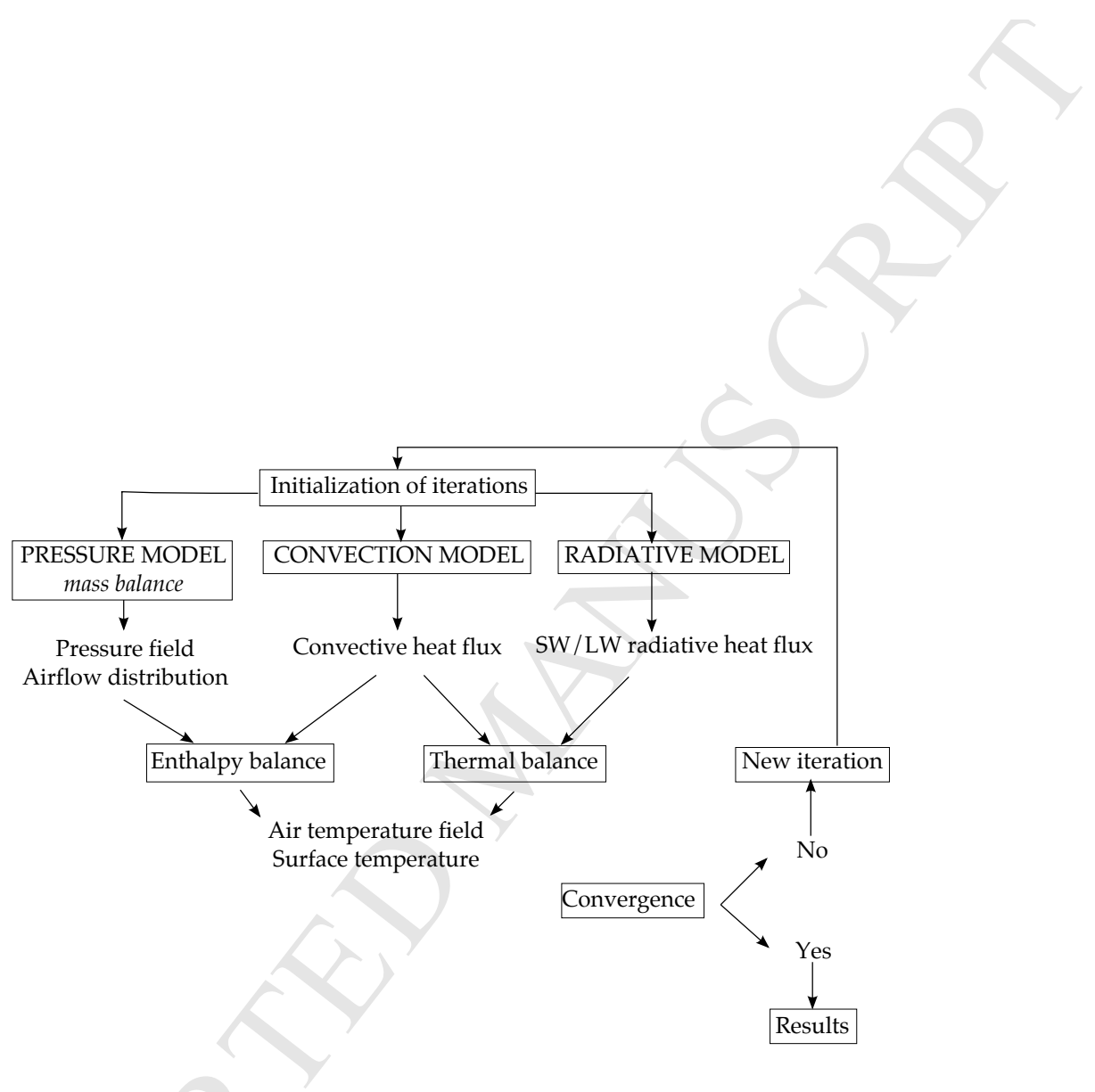

Figure 7: Model resolution algorithm. 

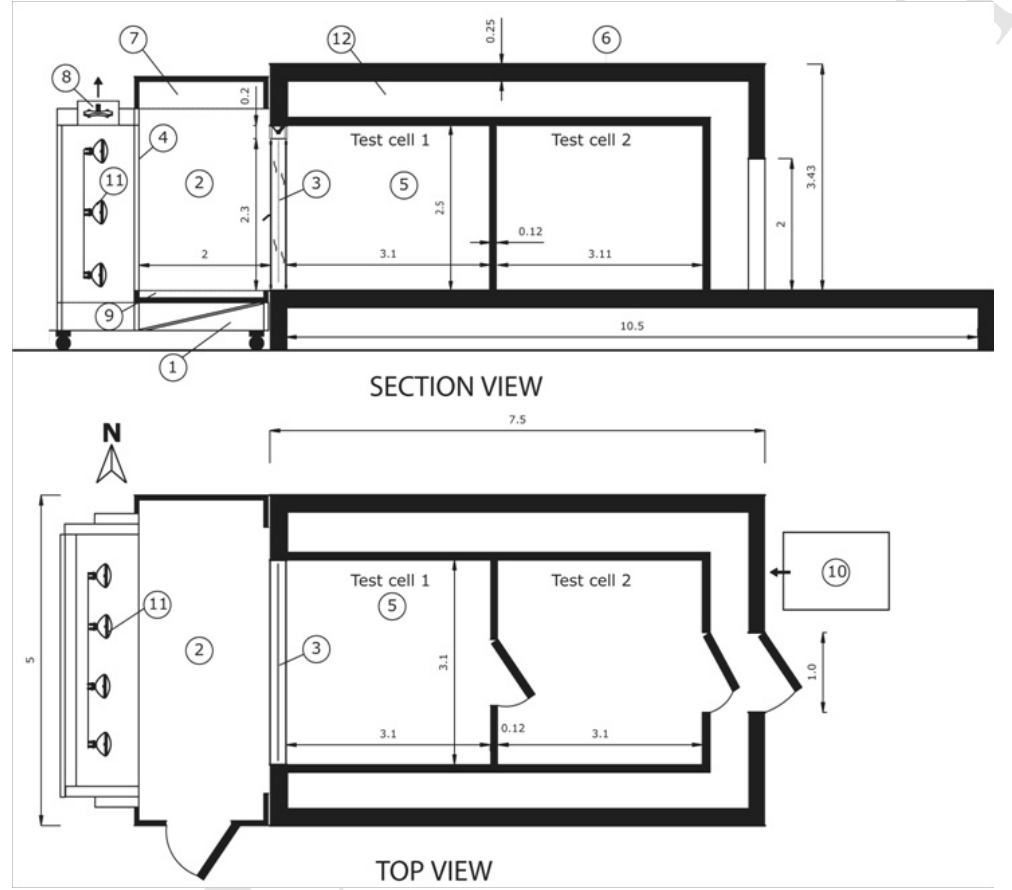

Figure 8: Test cell facility scheme: 1, cooling unit; 2, weather generator; 3 , double skin façade; 4, protection glass of the solar simulator; 5 , test cell; 6 , concrete; 7 , air blowing plenum; 8, solar simulator's heat removal ventilators; 9, air extraction plenum; 10, HVAC unit of the buffer zone; 11, solar simulator; 12, controlled buffer zone. (Metric units) [16]. 

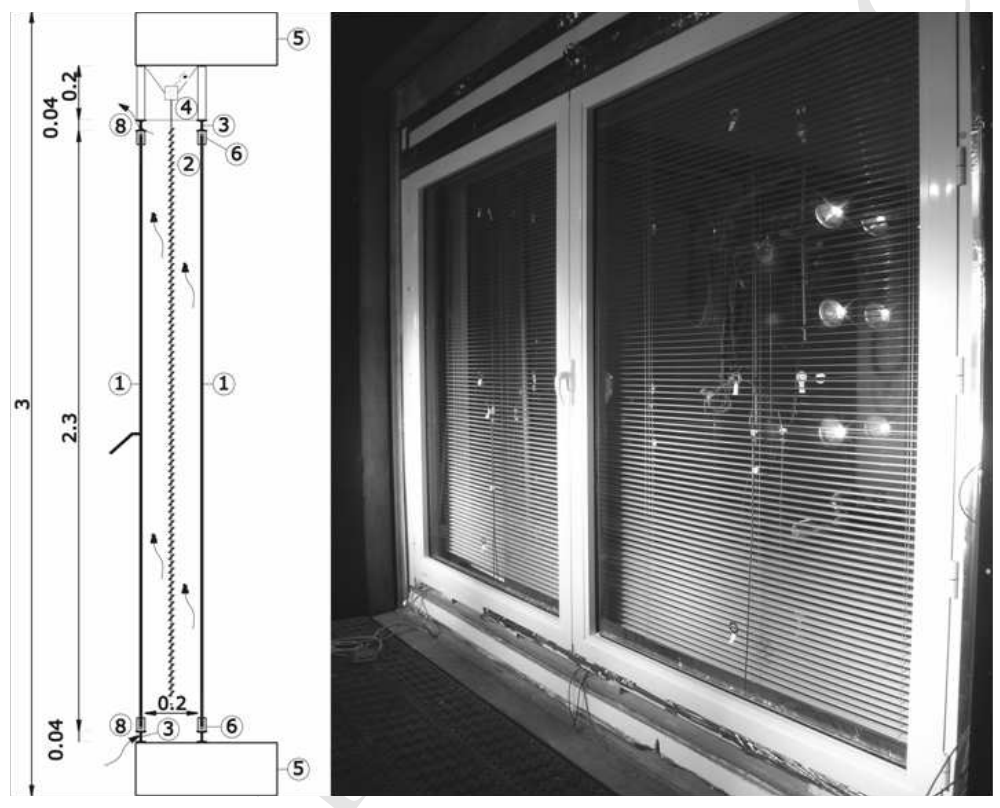

Figure 9: DSF section view: 1, $6 \mathrm{~mm}$ glass layer; 2, solar protections; 3 , metallic support; 4 , solar protection action box; 5 , concrete beam; 6 , aluminum frame; 7 , pane opening articulation; 8, ventilation openings. (Metric units) [16]. 

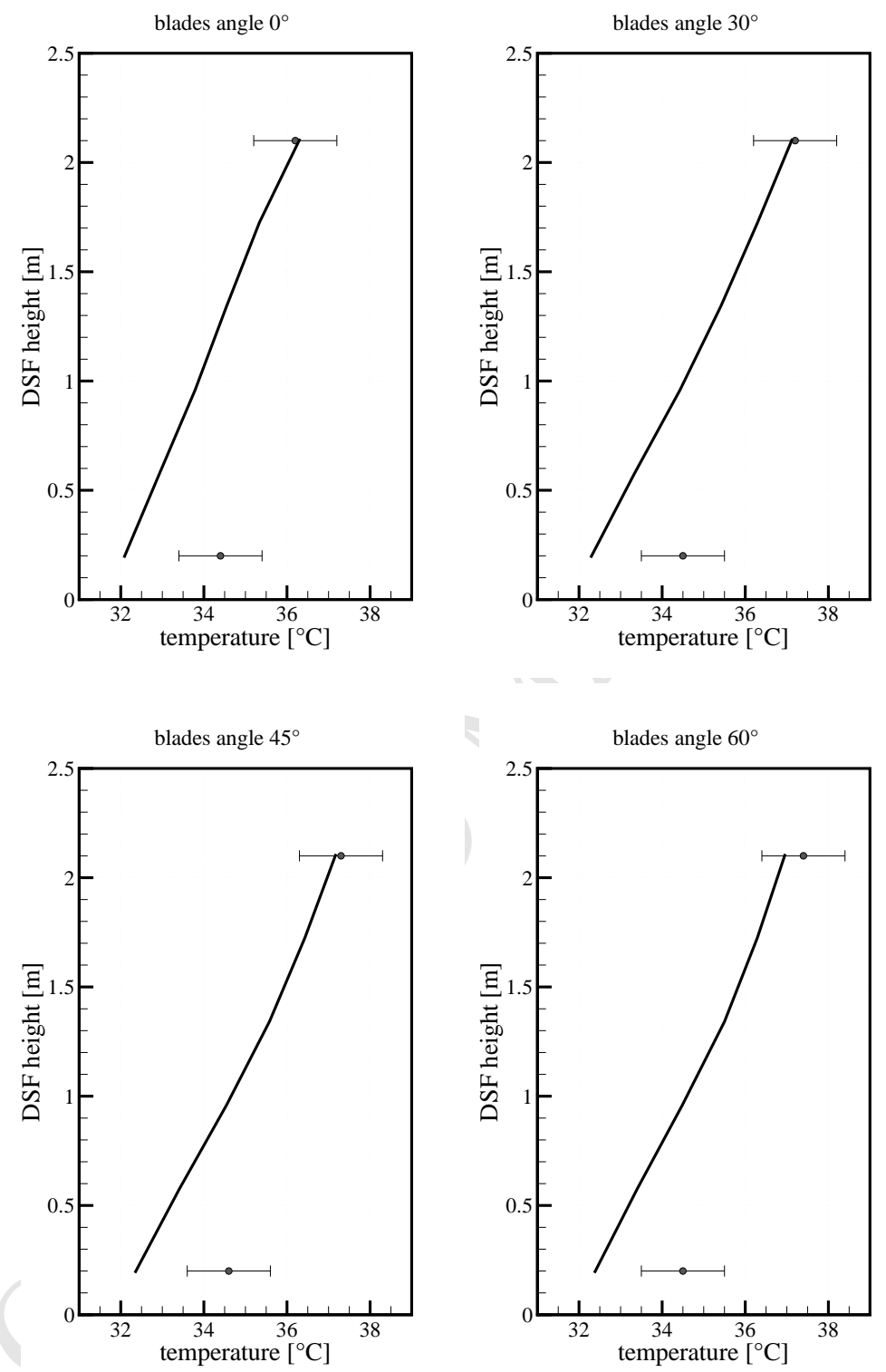

Figure 10: Air temperature profile in the left channel of the DSF for an airflow equal to $400 m^{3} h^{-1}$ - circle: experimental data and line: numerical modelling. 

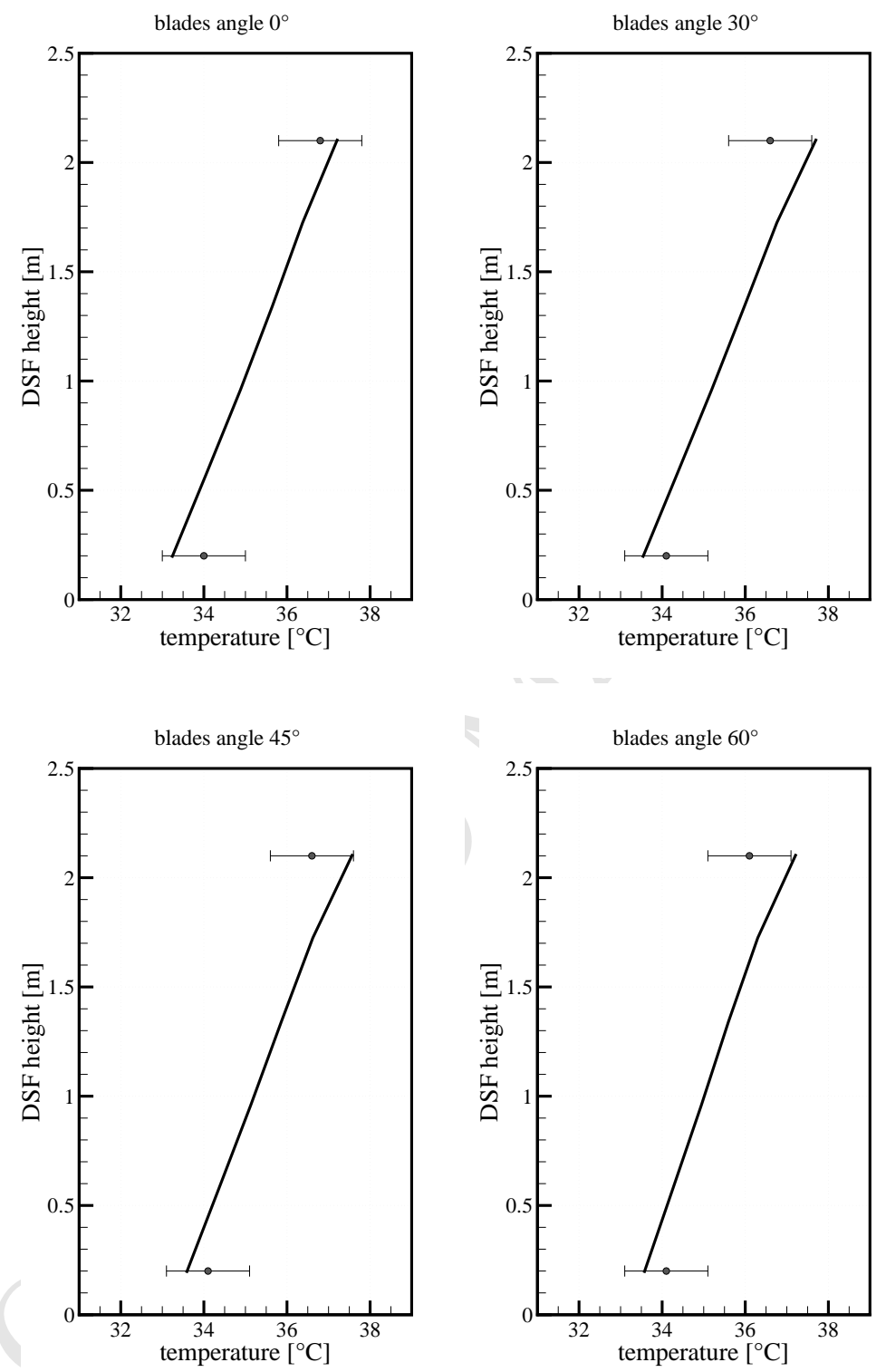

Figure 11: Air temperature profile in the right channel of the DSF for an airflow equal to $400 m^{3} h^{-1}$ - circle: experimental data and line: numerical modelling. 

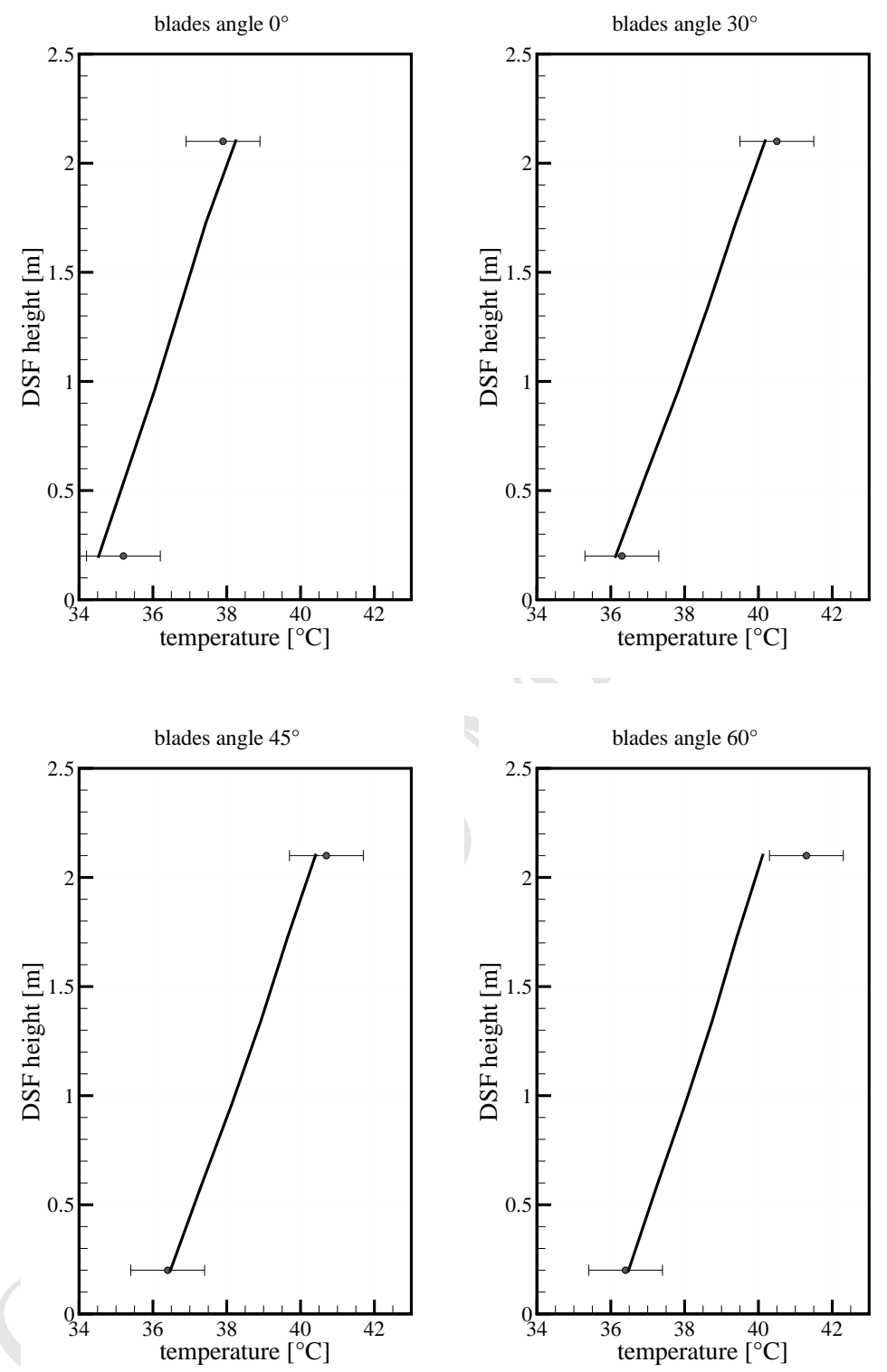

Figure 12: Venetian blades temperature for an airflow equal to $400 m^{3} h^{-1}$ - circle: experimental data and line: numerical modelling. 

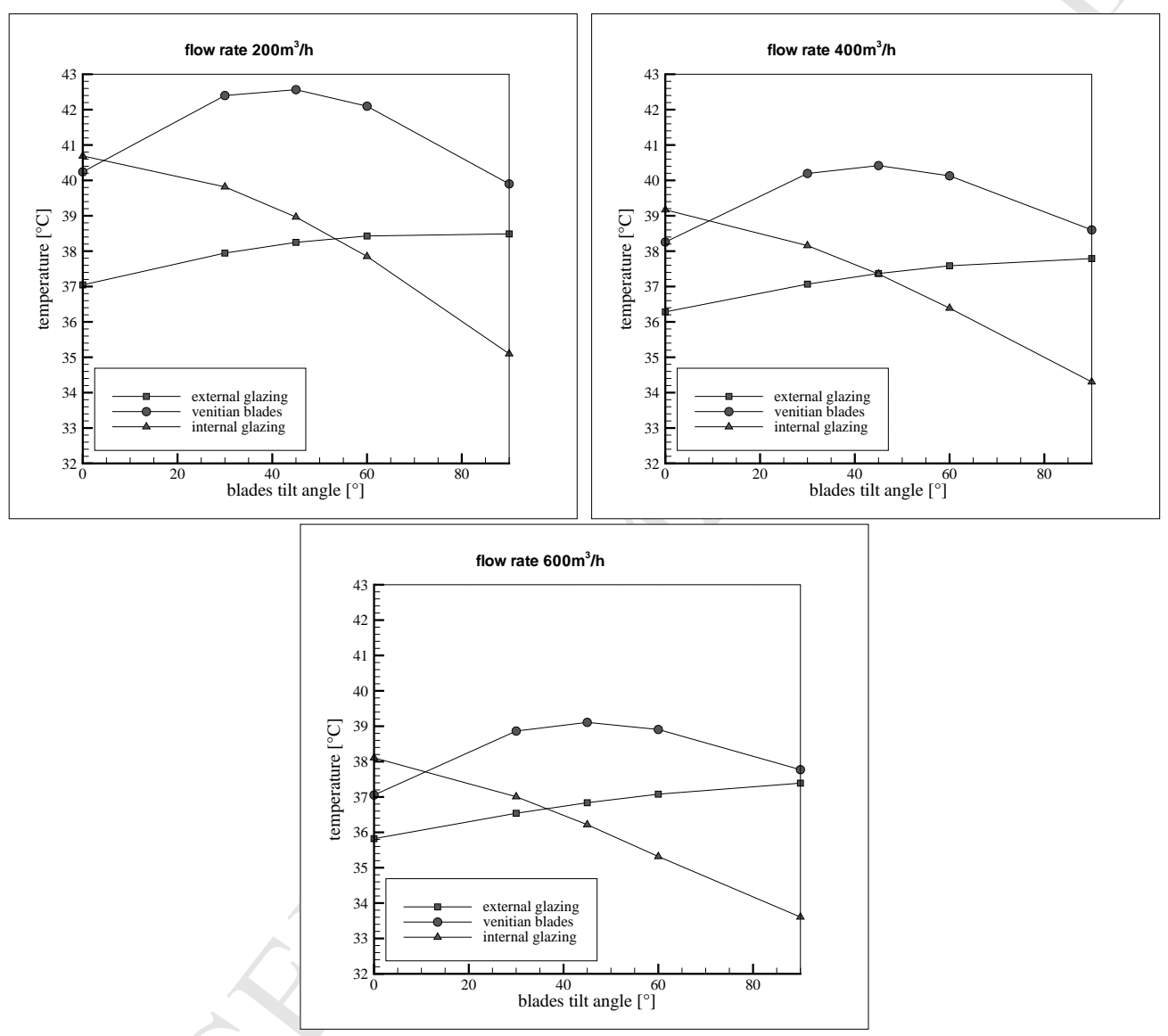

Figure 13: Temperature variation in the DSF for different air flows and blades tilt angles - Numerical modelling. 